\title{
Promoting effect of potassium solubilizing bacteria (Bacillus cereus) on nutrients availability and yield of potato
}

\author{
Ali A. M., Awad M. ${ }^{*}$, Hegab S. A., Abd El-Gawad A. \\ Department of Soils and Water, Faculty of Agriculture, Al-Azhar University, 71524 Assiut, Egypt
}

\begin{abstract}
A field experiment was carried out during 2017/18 - 2018/19 seasons at the agricultural experimental farm, Faculty of agricultural, Al-Azhar University, Assiut, Egypt, in a randomized complete block design (RCBD) with three replicates. This study aims to assess the performance of bio-fertilization (Bacillus cereus) as potassium solubilizing bacteria (KSB) on the growth of potato tuber and availability of $\mathrm{N}, \mathrm{P}$ and $\mathrm{K}$ as well as soil peering potassium additives. The results showed that the application of bio fertilizer significantly increased plant height $(\mathrm{PH})$, branches number $(\mathrm{BN})$, tuber weight and potato yield by about 14,27 , and $11 \%$, respectively, compared to the untreated one. The $\mathrm{N}, \mathrm{P}$, and $\mathrm{K}$ uptake were significantly increased in the plants inoculated with Bacillus cereus compared to the un-inoculated plants. Nitrogen, phosphorus and potassium use efficiency values increased by $50 \%$ over the untreated plants to for all tested nutrients. An increasing in the graded weights of potato for large $(17.71 \%)$, medium $(3.62 \%)$ and small size $(19.95 \%)$ of tubers and the total yield $(11.19 \%)$ increment compared to the untreated plots. Also, Nitrogen, phosphorus and potassium use efficiency values increased by $50 \%$ over the untreated plants to for all tested nutrients.
\end{abstract}

Keywords: bio-fertilizer, potato yield, nutrient availability, uptake.

*Corresponding author: Awad M.,

E-mail address: mahrousawad.4419@azhar.edu.eg 


\section{Introduction}

Potato (Solanum tuber sum L.) is one of the world's major staple crops after rice, wheat and maize due to its nifty yield potential and high nutritious value (Kumar et al., 2012). It is contain 70-82\% water, $17-29 \%$ dry matter, $11-23 \%$ carbohydrate, $0.8-3 \%$ protein, $0.1 \%$ fat, and $1.1 \%$ minerals as well as it has rich source of starch, vitamin $\mathrm{C}$, and B which leads to being the food of future (Khurana and Naik, 2003; Myers, 2011). Also, it occupied about 9 million ha and its production is about 365 million tons (FAO, 2014). In Egypt, the cultivated area of potato crop in 2010 was about 335 thousand feddans (feddan $=0.420$ hectares $=1.037$ acres) (Abdallah et al., 2015). In last decades, bio-fertilizers have been used in increasing crop production to supply it with nutrients; stimulate plant growth through the production of plant hormones; inhibit the activity of plant pathogens; improve soil structure; bioaccumulation or microbial leaching of inorganics (Brierley, 1985; Davison, 1988; Ehrlich, 1990). Pseudomonas and Bacillus which known as potassium solubilizing bacteria (KSB) in silicate form play an important role in case of potassium (Nurali et al., 2005) and its application is useful at growth of different plants (Xiao et al., 2017).It is suggested as a solution for improve plant nutritive; enzyme activation, maintaining cell turgor; transportation of sugars and starches; improving crop quality; increasing resistance against stress condition such as pests and diseases, reduce nitrate and nitrite contents of potato tubers (Abou-Hussein et al., 2002; Meena et al., 2014). Moreover, KSB plays an essential role in improving soil fertility; production, and reduce the amount of chemical fertilizers (Zhang et al., 2013). Bio-fertilizers are applied to the soil or plant in order to reduce the uses of chemical fertilizers (Bojórquez et al., 2010). However, continuous and excessive use of chemical fertilizers cause health and environmental hazards, deterioration in soil properties and consequently crop shortages. Therefore, using different microbial strains as bio fertilizers has led to a decrease in the use of chemical fertilizers and has provided high quality goods free of agrochemicals harmful and safety for human consumption (El Naim et al., 2017). An increase in some growth parameters such as plant weight, number of large tubers, and total tubers was recorded as a result of the addition of bio-fertilizers individually or in combination with organic and inorganic amendments (Singh et al., 2017). Furthermore, the application of bio-fertilizer supports the conditions of root growth, increase the growth, and finally improve the biological functions of the plant (El-Azab and Camilia, 2018). There is a lack of information on the use of bio-fertilizers such as potassium solubilizing bacteria in potato production as substitute for the use of chemical fertilization to be free of chemicals. So, the current study aims to investigate the effect of bio-fertilization on the growth and potato yield as well as soil bearing potassium. 


\section{Materials and methods}

\subsection{Field experiment}

The present study was carried out during the seasons of 2017/18 (30 September) and 2018/19 ( $1^{\text {st }}$ October $)$ at the agricultural experimental farm, Faculty of agricultural, Al-Azhar university, Assiut, Egypt, which is located at $27^{\circ} 12^{-} 16.67^{-}$ $\mathrm{N}$ latitude and $31^{\circ} 09^{-} 36.86^{\circ} \mathrm{E}$ longitude. The tested bio-fertilizer (Bacillus cereus as potassium solubilizing bacteria) was obtained from the National Research Center, Giza, Egypt. These bacteria were added after the emergence of potato plants and once again after one week to guarantee their function. The experimental plot has an area of $10.5 \mathrm{~m}^{2}$ ( $3 \mathrm{~m}$ width $\times 3.5 \mathrm{~m}$ length). According to the Egyptian Ministry of Agriculture and
Land Reclamation, super-phosphate $\left(15.5 \% \mathrm{P}_{2} \mathrm{O}_{5}\right)$ was added at a rate of 75 $\mathrm{Kg} \mathrm{P} /$ fed during land preparation. Nitrogen fertilizer (urea, $46 \% \mathrm{~N}$ ) at a rate of $120 \mathrm{~kg} \mathrm{~N} / \mathrm{fed}$ was divided into three equal doses and was added at 30,60 and 90 days after planting. Each plot received a mixture sources of feldspar, filter mud cake and potassium sulfate at the time of nitrogen fertilization (each source was about $24 \mathrm{~kg} \mathrm{~K} / \mathrm{fed}$ ).Plant samples were collected at harvest stage $\left(30^{\text {th }}\right.$ January 2018 and $1^{\text {st }}$ February 2019) and the growth parameters (plant height, branches number, fresh weight and yield weight) were recorded. The collected samples were cleaned, washed with tap and distilled water, air dried, and then oven dried at $70^{\circ} \mathrm{C}$ until constant weight, ground and stored for chemical analysis. Some physiochemical properties of the cultivated soil were listed in Table (1).

Table (1): Some physical and chemical properties of cultivated soil

\begin{tabular}{lcc}
\hline Properties & Units & Value \\
\hline Sand & $\left(\mathrm{g} \mathrm{kg}^{-1}\right)$ & 535 \\
\hline Silt & $\left(\mathrm{g} \mathrm{kg}^{-1}\right)$ & 223 \\
\hline Clay & $\left(\mathrm{g} \mathrm{kg}^{-1}\right)$ & 242 \\
\hline Texture & ---- & Sandy clay loam \\
\hline CaCO3 & $\left(\mathrm{g} \mathrm{kg}^{-1}\right)$ & 14 \\
\hline $\mathrm{pH}(1: 2.5)$ & ----- & 8.04 \\
\hline EC $(1: 1)$ & $\left(\mathrm{dS} \mathrm{m}^{-1}\right)$ & 1.4 \\
\hline Organic matter & $\left(\mathrm{g} \mathrm{kg}^{-1}\right)$ & 13.8 \\
\hline Total N & $\left(\mathrm{mg} \mathrm{kg}^{-1}\right)$ & 300 \\
\hline Total P & $\left(\mathrm{mg} \mathrm{kg}^{-1}\right)$ & 297 \\
\hline Total K & $\left(\mathrm{mg} \mathrm{kg}^{-1}\right)$ & 394 \\
\hline Available N & $\left(\mathrm{mg} \mathrm{kg}^{-1}\right)$ & 53 \\
\hline Available $\mathrm{P}($ Olsen $)$ & $\left(\mathrm{mg} \mathrm{kg}^{-1}\right)$ & 8.5 \\
\hline Available K & $\left(\mathrm{mg} \mathrm{kg}^{-1}\right)$ & 92.6 \\
\hline Each value represents a mean of three replicates. &
\end{tabular}




\subsection{Soil and plant analysis}

Particle-size distribution was carried out by using the pipette method according to (Jackson, 1973). The soil pH was measured in 1:2.5 (Soil: water) suspension and the electrical conductivity (EC) was measured in 1:1 extract (Jackson, 1973). Soil organic matter was determined by wet oxidation method by $\mathrm{K}_{2} \mathrm{Cr}_{2} \mathrm{O}_{7} 1 \mathrm{~N}$ and $\mathrm{H}_{2} \mathrm{SO}_{4}$ (Baruah and Barthakur, 1997). Total and Available nitrogen was measured according to Jackson (1973). The available phosphorus was measured according to Olsen et al. (1954). The available potassium was measured by flame photometer (Jackson, 1973). Total phosphorus was measured in the soil samples by digestion using $20 \mathrm{ml}$ of a mixture of 7:3 ratio of sulfuric to perchloric acids. Total calcium carbonate was determined by Collin's calcimeter according to Nelson (1982). Dried grounded plant material of $0.2 \mathrm{~g}$ was digested using $10 \mathrm{~mL}$ of a mixture of $7: 3$ ratio of sulfuric to perchloric acids (Jackson, 1973). Total nitrogen, phosphorus and potassium were measured according to Jackson (1973). Use efficiency of applied nitrogen (UEN), phosphorus (UEP) and potassium (UEK) were calculated using the following equation: tubers yield of the treatments $(\mathrm{kg} / \mathrm{fed})$ - tubers yield of the control (kg/fed)/ N, P and K applied level (kg/fed.

\section{Results and Discussion}

\subsection{Growth and potato tubers yield}

Data in Figure (1) show some growth parameters of potato plants at full blooming stage. The bio-fertilization significantly $(P<0.05)$ increased the plant high $(\mathrm{PH})$ and branches number $(\mathrm{BN})$. The increases were 14.00 and $26.86 \%$ for the $\mathrm{PH}$ and $\mathrm{BN}$, respectively above the control. These results are in agreement with those of many investigators who reported that the bio-fertilization increased potato growth (Abdel-Salam and Shams, 2012; Anjanadevi et al., 2016). These increases in vegetative growth might be due to the increases in the soil microbial flora that could solubilize potassium from the feldspar with continues supply of $\mathrm{k}$ which lead to enhance plant grow this a result of biofertilization (Parmar and Sindhu, 2013; Zaki et al., 2012). However, the results suggested that the inoculation with Bacillus cereus resulted in increases in the dry weight content by about $24.21 \%$ above the control. This might be due to early growth which facilitates the plant to attain maximum dry weight content (Kabir, 2014). This result was similar with that reported by Mahamud et al. (2015). Moreover, the results recorded a total yield of 16.67 ton/fed with $11.19 \%$ increment compared to the untreated plots. Similar results were pointed out by Abdel-Salam and Shams (2012) and Labib et al. (2012) on potato, Abd-ElHakeem and Fekry (2014) on sweet potato. The increases in the total yield of potato crop may be due to the promotion of nutrients uptake and enhancement of plant growth through its ability to produce plant hormones as a result of inoculation with Bacillus circulars (Youssef et al., 2010). 


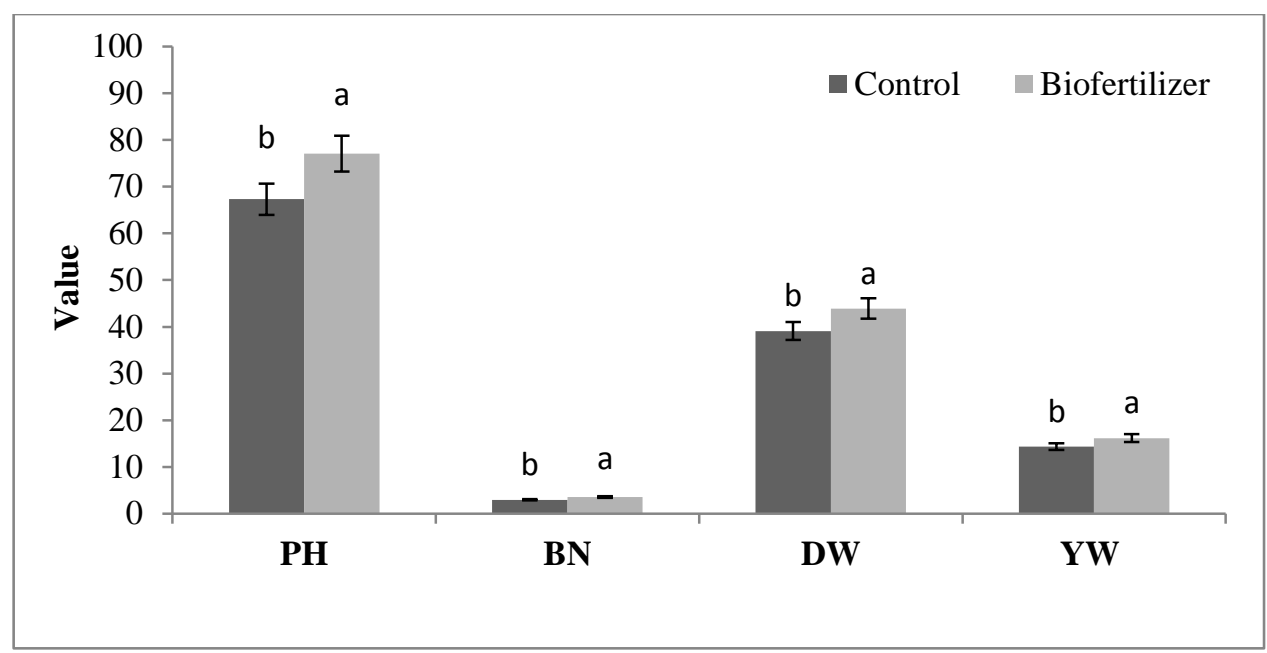

Figure (1): Effect of bio fertilizer on the growth parameter of potato plants as average of both seasons. $\mathrm{PH}=$ plant high $(\mathrm{cm}), \mathrm{BN}=$ branches number /plant, DW=dray weight $\left(\mathrm{g} \mathrm{tuber}^{-1}\right), \mathrm{YW}=$ yield weight (ton/fed).Means denoted by different letters are significantly difference according to Duncan's test at $P<0.05$.

3.2 Nitrogen, phosphorus, and potassium concentration and their uptake by potato plants

The effect of bio-fertilization on the uptake of nitrogen $(\mathrm{N})$, phosphorus $(\mathrm{P})$ and potassium $(\mathrm{K})$ are shown in Figure (2). The uptake of $\mathrm{N}, \mathrm{P}$, and $\mathrm{K}$ in potato plants were significantly $(\mathrm{P}<0.05)$ affected by bio-fertilizer application. The obtained results demonstrated that $\mathrm{N}, \mathrm{P}$, and $\mathrm{K}$ uptake increased by $34.28,32.37$ and $63.58 \%$, respectively, compared to untreated plots. Improving the availability of these nutrients may be through the production of organic acids and other chemicals, which stimulates plant growth and uptake of nutrients. Similar results were reported by Abdel-Salam and Shams (2012) and Labib et al. (2012) who found that the inoculation with Bacillus circulans on potato plants increased the uptake of N, P and K. Also, combined effect of potassium dissolving bacteria with $\mathrm{K}$ and P-bearing minerals on sorghum enhanced phosphorus uptake by $71 \%, 110 \%$ and $116 \%$, and $\mathrm{K}$ uptake by $41 \%, 93 \%$, and $79 \%$ in clay, sandy and calcareous soils, respectively (Badr et al. 2006). Inoculation with bio fertilizer (Bacillus circulans) could improve $\mathrm{P}$ and $\mathrm{K}$ and micro nutrients availability by producing organic acids and other chemicals, which stimulate growth and nutrients plant uptake (El kholy et al., 2012). The impact of bio-fertilization on the concentration of $\mathrm{N}, \mathrm{P}$, and $\mathrm{K}$ was investigated at harvest stage (Figure 3). The results demonstrated that the concentration of $\mathrm{N}, \mathrm{P}$, and $\mathrm{K}$ in potato plants significantly $(P<0.05)$ increased by $7.39,6.08$ and $30.91 \%$, respectively, as a result of using bio fertilizers. Similar results were reported by Prajapati et al. (2013) and Shehata et al. (2014) who found that the $\mathrm{N}, \mathrm{P}$, and $\mathrm{K}$ concentrations 
were high in okra plants due to using biofertilizer. These increases might be due to the high activity of potassium dissolving bacteria which shows their ability to live zone rhizosphere at high number in the presence of the feldspar rock and/or converting of the unavailable forms of mineral nutrient to available forms (Hassan et al., 2006; Kandeel and Sharaf, 2003).

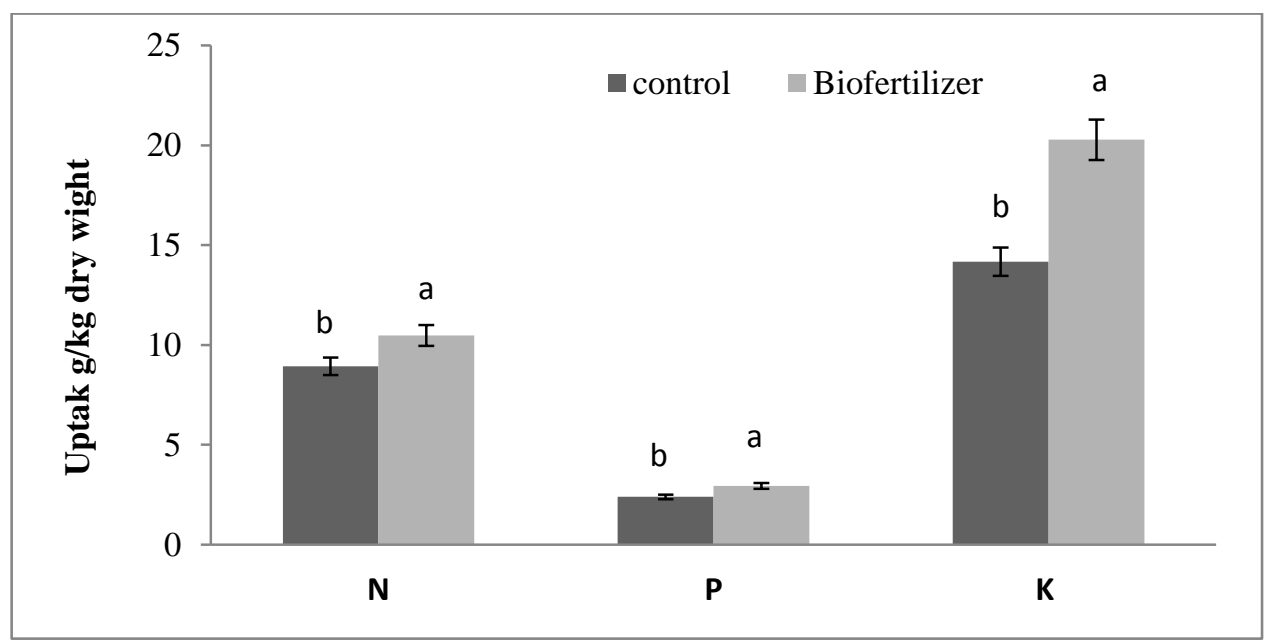

Figure (2): Effect of bio fertilizer on N, P and K uptake by potato plants as average of both seasons. Means denoted by different letters are significantly difference according to Duncan's test at $P<0.05$.

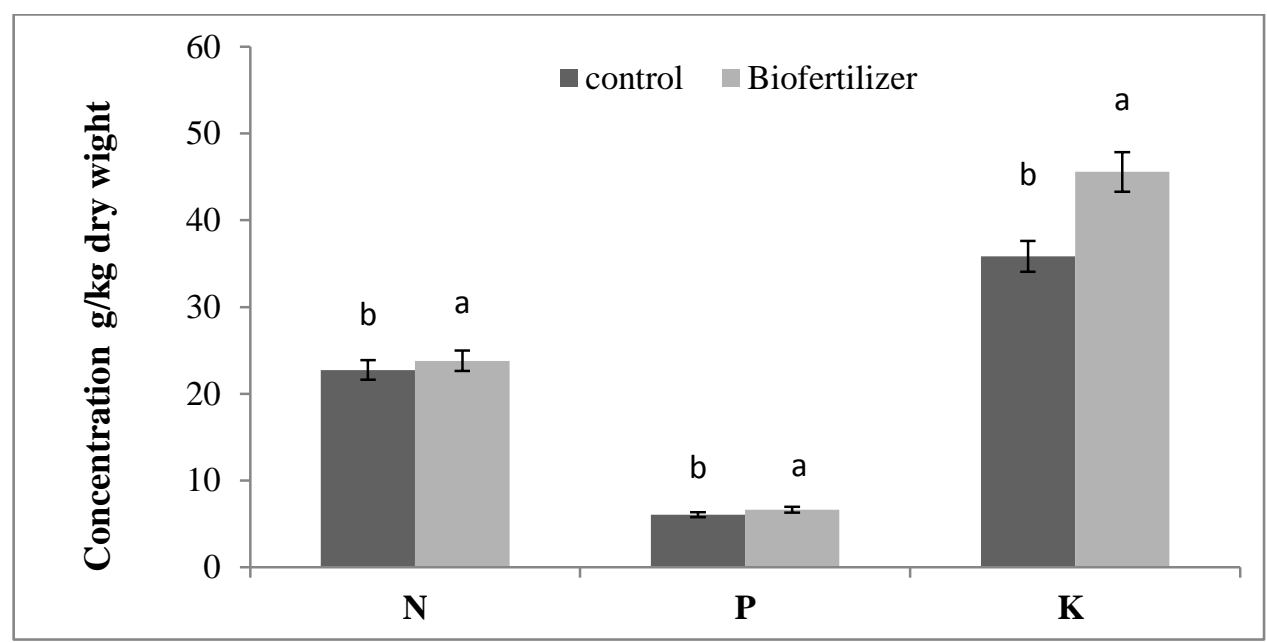

Figure (3): Effect of bio fertilizer on the concentration of N, P and $\mathrm{K}$ of potato tubers as average of both seasons. Means denoted by different letters are significantly difference according to Duncan's test at $P<0.05$. 


\subsection{Potato tubers graded}

The graded weight of large, medium and small size tubers of potato plants were significantly $(\mathrm{P}<0.05)$ affected by biofertilizer application compared to the untreated one (Figure 4). The results clearly indicated that the graded weights of potato were increased by $17.71,3.62$ and $18.95 \%$ for large, medium and small size of tubers, respectively as a result of applying bio-fertilizer. The increase in total yield and the graded weight of tubers may be due to the increase in the number of stems, the role of potassium on photosynthesis, translocation through phloem, and production of large molecular weight substances (such as starch) within storage organs, which contribute in the rapid size of the potato tubers (Abd El Gawad, 2009; Sharma and Sud, 2001).

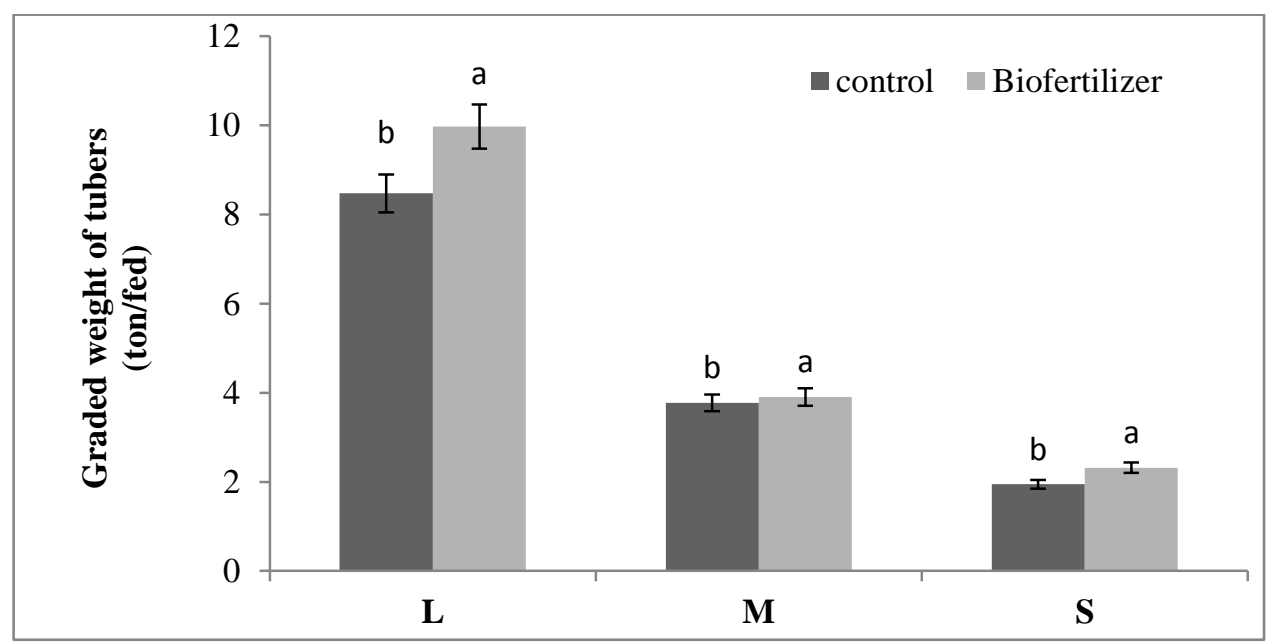

Figure (4): Effect of bio fertilizer on the graded weight of potato tubers as average of both seasons. L=Large Size (ton/fed), M= Medium Size (ton/fed), S= Small Size (ton/fed). Means denoted by different letters are significantly difference according to Duncan's test at $P<0.05$.

\subsection{Soil properties}

Some soil properties in relation to biofertilization are shown in Table (2). Inoculation with bio-fertilizers (Bacillus cereus) resulted in an increase in the soil reaction and organic matter by 1.97 and $6.10 \%$, respectively over the uninculcated one. Similar results were reported by Lima et al. (2010) and Niewia domska (2013) who observed that potential of free-living bacteria to increase organic matter of soil due to increase the produce numerous bioactive substances in soil. Available of N, P and $\mathrm{K}$ was significantly $(P<0.05)$ increased due to bio fertilizers treatments to reach $2.55,2.96$ and $40.11 \%$, respectively, compared to the untreated one. Similar results were obtained by Abou-el-Seoud and Abdel-Megeed (2012). The increasing of $\mathrm{K}$ availability may be due 
the $\mathrm{K}$ solubilization from feldspar and increased microbial activity in the rhizosphere of plants (Abou-el-Seoud and Abdel-Megeed, 2012). So, the partial break down of feldspar by AMmycrrhizal fungi and $B$. circulars bacteria promote the release of nutrients (Massoud et al., 2009).

Table (2): Effect of bio fertilizer on some soil chemical properties (average of two seasons).

\begin{tabular}{lcc}
\hline Variable & Control & Bio-fertilizer \\
\hline $\mathrm{pH}(1: 2.5)$ & $8.00 \mathrm{~b}$ & $8.16 \mathrm{a}$ \\
\hline $\mathrm{EC}(1: 1)\left(\mathrm{dsm}^{-1}\right)$ & $1.47 \mathrm{a}$ & $1.48 \mathrm{a}$ \\
\hline Organic matter $(\%)$ & $1.52 \mathrm{~b}$ & $1.62 \mathrm{a}$ \\
\hline Available $\mathrm{N}\left(\mathrm{mg} \mathrm{kg}^{-1}\right)$ & $77.92 \mathrm{~b}$ & $79.91 \mathrm{a}$ \\
\hline Available P $\left(\mathrm{mg} \mathrm{kg}^{-1}\right)$ & $8.55 \mathrm{~b}$ & $8.80 \mathrm{a}$ \\
\hline Available K $\left(\mathrm{mg} \mathrm{kg}^{-1}\right)$ & $200.91 \mathrm{~b}$ & $281.50 \mathrm{a}$ \\
\hline
\end{tabular}

Means in the same row denoted by different letters are significantly difference according to Duncan's test at $P<0.05$.

\subsection{Nutrients use efficiency}

Nutrient use efficiency is a highly important concept for evaluating crop production systems. Nutrients use efficiency are considered as a function of the soil capacity to supply sufficient amount of nutrients and the ability of plants to uptake them (Baligar et al., 2001). Effect of bio-fertilizer application on nutrients use efficiency is shown in (Figure 5).

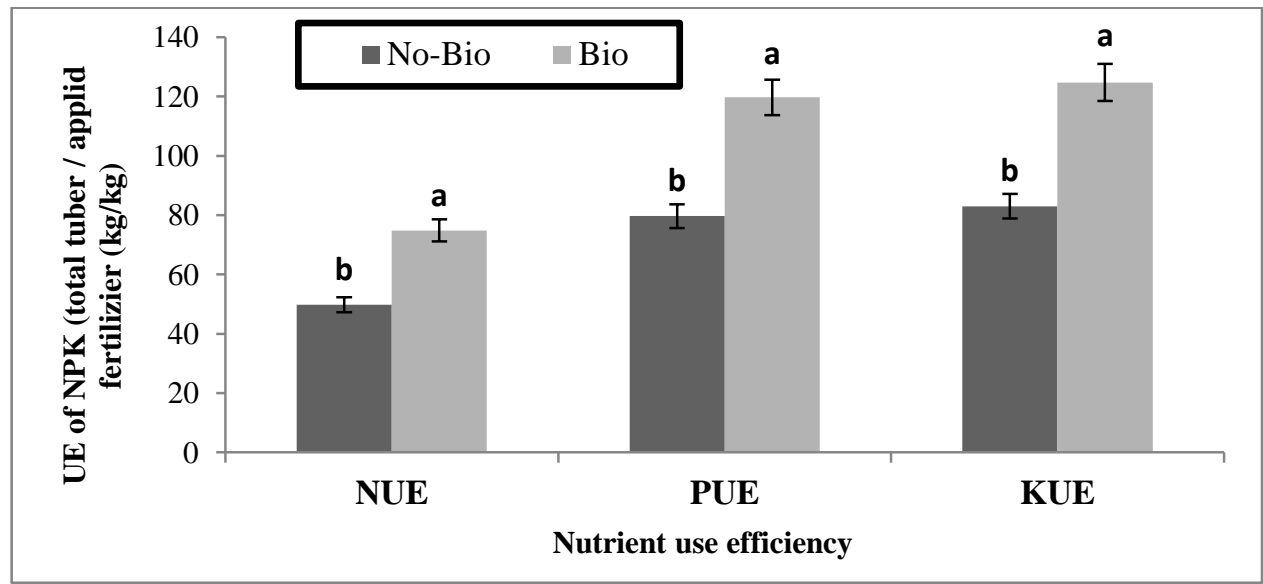

Figure (5). Effect of bio-fertilizers application on nutrients use efficiency. NUE= Nitrogen use efficiency, PUE $=$ Phosphorus use efficiency and KUE $=$ Potassium use efficiency.

Nitrogen, phosphorus and potassium use efficiency values increased by $50 \%$ over the untreated plants to for all tested nutrients. The increases in the nutrient use efficiencies may be due to release these nutrients gradually by solubilizing bacteria and produced organic acids as a result of bio fertilizers application. This result in compatible with those obtained by Dawwam et al. (2013) who indicated 
that the use of potassium solubilizing bacteria as bio fertilizer was a sustainable solution to improve plant growth, nutrition, root growth, plant competitiveness due its role in solubilize rock-K mineral powder through production and excretion of organic acids or chelate silicon ions to bring $\mathrm{K}$ into solution which lead to increasing nutrient use efficiency.

\section{Conclusions}

The use of bio fertilization to reduce mineral fertilization and to obtain clean food has become a vital issue. The potassium solubilizing bacteria improved the growth parameters of potato plant than the untreated plants. Inoculation with Bacillus cereus bacteria resulted in a significant increase in the plant height and dry biomass as well as it increased the availability and NPK uptake. Moreover, the bio fertilizers increased the total yield and enhanced the graded weight of potato tubers. Nitrogen, phosphorus and potassium use efficiency values increased by $50 \%$ over the untreated plants to for all tested nutrients. Therefore, we recommend using bio fertilization for potato plants to increase its production in an organic farming that enhance its opportunity for exporting.

\section{References}

Abdallah, O. M., Hessen. Y. A and Abdel Magied Sozan (2015), "Economic study of production and consumption of potato in Egypt",
Assiut Journal of Agriculture Sciences, Vol. 46 No. 1, pp. 58-67.

Abd El gawad, A. M. A. (2009), Effect of different levels of nitrogen and potassium on the growth yield and quality of potato grown in newly reclaimed land, M.Sc. Thesis, Faculty of Agriculture, Minia University, Minia, Egypt.

Abd El-Hakeem, S. S. and Fekry, W. A. (2014), "Effect of K-feldspar, potassium sulfate and silicate dissolving bacteria on growth, yield and quality of sweet potato plants". Zagazig Journal of Agricultural Research, Vol. 41 No 3, pp. 467477.

Abdel-Salam, M. A. and Shams, A. S. (2012), "Feldspar-K fertilization of potato (Solanum tuberosum L.) augmented by biofertilizer", American-Eurasian Journal of Agricultural \& Environmental Sciences, Vol. 12 No. 6, pp. 694699.

Abou-el-Seoud, I. I. and Abdel-Megeed, A. (2012), "Impact of rock materials and bio fertilizations on $\mathrm{P}$ and $\mathrm{K}$ availability for maize (Zea maize) under calcareous soil conditions", Saudi Journal of Biological Sciences, Vol. 19 No. 1, pp. 55-63.

Abou-Hussein, S. D., El-Shorbagy, T. and Abou-Hadid, A. F. (2002), "Effect of cattle and chicken manure with or without mineral fertilizers on tuber quality and yield of potato 
crops", ISHS Acta Horticulturae 608: International Symposium on The Horizons of Using Organic Matter and Substrates in Horticulture, Vol. 10 No 12, pp. 95100.

Anjanadevi, I. P., John, N. S., John, K. S., Jeeva, M. L. and Misra, R. S. (2016), "Rock inhabiting potassium solubilizing bacteria from Kerala, India: characterization and possibility in chemical $\mathrm{K}$ fertilizer substitution", Journal of basic microbiology, Vol. 56 No. 1, pp. 6777.

Badr, M. A., Shafei, A. M. and Sharaf El-Deen, S. H. (2006),"The dissolution of $\mathrm{K}$ and P-bearing minerals by silicate dissolving bacteria and their effect on sorghum growth", Research Journal of Agriculture and Biological Sciences, Vol. 2 No. 1, pp. 5-11.

Baligar, V. C., Fageria, N. K. and He, Z. L. (2001), "Nutrient use efficiency in plants", Communications in Soil Science and Plant Analysis, Vol. 32 No. 7-8, pp. 921-950.

Baruah, T. C. and Barthakur, H. P. (1997), A Textbook of Soil Analysis, Vikas Publishing House PVT LTD, New Delhi, India.

Bojórquez, A. D. A., Gutiérrez, C. G., Báez, J. R. C., Sánchez, M. Á. A., Montoya, L. G. and Pérez, E. N. (2010), "Bio fertilizations en el desarrollo agrícola de México", $R a$
Ximhai: revista científica de sociedad, cultura y desarrollo sostenible, Vol. 6 No 1, pp. 51-56.

Brierley, J. A. (1985), "Use of microorganisms for mining metals", Halvorson, H. et al. (Eds.), Engineered Organisms in the Environment: Scientific Issues, Proceedings of a Cross-Disciplinary Symposium Held in Philadelphia, Pennsylvania, USA, pp. 10-13.

Davison, J. (1988), "Plant beneficial bacteria", Bio/Technology, Vol. 6 No. 3, pp. 282-286.

Dawwam, G. E., Elbeltagy, A., Emara, H. M., Abbas, I. H and Hassan, M. M. (2013), "Beneficial effect of plant growth promoting bacteria isolated from the roots of potato plant", Annals of Agricultural Sciences, Vol. 58 No. 2, pp. 195201.

Ehrlich, H. L. (1990), Geomicrobiology, $2^{\text {nd }}$ eds., Dekker, New York, USA, pp. 646.

El kholy, M. M., El-Tohamy, S. A and Hafez, W. A. (2012), "Rationalization of mineral potassium fertilizer by using biodesolving potassium and its effect on yield and quality potatos", Journal of Soil Sciences and Agricultural Engineering, Vol. 3 No. 12, pp. 1275-1285.

El Naim, A. M., Ahmed, A. I., Ibrahim, K. A., Suliman, A. M. and Babikir, 
E. S. (2017), "Effects of nitrogen and bio-fertilizers on growth and yield of roselle (Hibiscus sabdariffa var sabdariffa L.)", International Journal of Agriculture and Forestry, Vol. 7 No. 6, pp. 145-150.

El-Azab, M. E. and El-Dewiny, C. Y. (2018), "Effect of bio and mineral nitrogen fertilizer with different levels on growth, yield and quality of maize plants", Journal of Innovations in Pharmaceutical and Biological Sciences, Vol. 5 No. 2, pp. 2349-2759.

FAO (2014), Food and Agriculture Organization of United Nations, FAOSTAT Database, Retrieved from http://faostat.fao.org.

Hassan, H., Dalia, R. N. and Abou-baker, M. H. A. (2006), "Effect of minerals and bio- fertilizers on growth and yield components, chemical constituents and anatomical structure of might plant grown under reclaimed soil conditions", Mansoura Journal of Agricultural Science, Vol. 31 No. 3, pp. 14331455.

Jackson, M. L. (1973), Soil Chemical Analysis, Prentice Hall of Englewood cliffs, New Jersey, USA.

Kabir, H. (2014), Effect of seed tuber size on the growth and yield of twenty three accessions of potato, M.Sc. Thesis, Department of Horticulture, Bangladesh Agricultural University, Mymensingh, Bangladesh.
Kandeel, A. M. and Sharaf, M. S. (2003),"Productivity of Majorana hortensis L. plants as influenced by the interactions between mineral and biological fertilization", Mansoura Journal of Agricultural Science, Vol. 28 No. 2, pp. 1373-1389.

Khurana, P. S. M. and Naik, P. S. (2003), "The Potato: An Overview", The Potato Production and Utilization in Sub-Tropics, Paul Khurana, S. M., Minas, J. S. and Pandy, S. K., Eds., Mehta Publication, New Delhi, India, pp. 1-14.

Kumar, M., Baishaya, L. K., Ghosh, D. C., Gupta, V. K., Dubey, S. K., Das, A. and Patel, D. P. (2012), "Productivity and soil health of potato (Solanum tuberosum L.) field as influenced by organic manures, inorganic fertilizers and bio fertilizers under high altitudes of eastern Himalayas", Journal of Agricultural Science, Vol. 4 No. 5, pp. 223-234.

Labib, B. F., Ghabour, T. K., Rahim, I. S. and Wahba, M. M. (2012)," Effect of potassium bearing rock on the growth and quality of potato crop (Solanum tuberosum)", Journal of Agricultural Biotechnology and Sustainable Development, Vol. 4 No. 1, pp. 7-15.

Lima, F. S., Stamford, N. P., Sousa, C. S., Junior, M. L., Malheiros, S. M. M. and Van Straaten, P. (2010), "Earthworm compound and rock bio fertilizer enriched in nitrogen by 
inoculation with free living diazotrophic bacteria", World Journal of Microbiology and Biotechnology, Vol. 26 No. 10, pp. 1769-1775.

Mahamud, M. A., Chowdhury, M. A. H., Rahim, M. A. and Sheel, P. R. (2015), "Performance of some potato accessions of USA and Bangladesh in relation to dry matter yield and biochemical constituent", Journal of the Bangladesh Agricultural University, Vol. 13 No. 2, pp. 215-220.

Massoud, O. N., Morsy, E. M. and ElBatanony, N. H. (2009), "Field response of snap bean (Phaseolus vulgaris L.) to N2-fixers Bacillus circulans and arbuscular mycorrhizal fungi inoculation through accelerating rock phosphate and feldspar weathering", Australian Journal of Basic and Applied Sciences, Vol. 3 No. 2, pp. 844-852.

Meena, V. S., Maurya, B. R. and Bahadur, I. (2014), "Potassium solubilization by bacterial strain in waste mica", Bangladesh Journal of Botany, Vol. 43 No. 2, pp. 235-237.

Myers, M. (2011), Potatoes Goodness Unearthed, The United States Potato Board, Denver, Colorado, USA.

Narula, N., Saharan, B. S., Kumar, V., Bhatia, R., Bishnoi, L. K., Lather, B. P. S., and Lakshminarayana, K. (2005), "Impact of the use of biofertilizers on cotton (Gossypium hirsutum) crop under irrigated agroecosystem", Archives of Agronomy and Soil Science, Vol. 51 No. 1, pp. 69-77.

Nelson, W. L. (1982), "Interaction of $\mathrm{k}$ with moisture and temperature", Potash Review, Vol. 1, pp. 16-87.

Sulewska, H., Ratajczak, K., Niewiadomska, A. and Panasiewicz, K. (2019), "The use of microorganisms as bio-fertilizers in the cultivation of white lupine", Open Chemistry, Vol. 17 No. 1, pp. 813-822.

Olsen, S. R., Cole, C. V., Watnabe, F. S. and Dean, L. A. (1954), Estimation of available phosphorus in soils by extraction with sodium bicarbonates, Vol. 939 of circular, United States Department of Agriculture, U.S. Department of Agriculture, Washington, DC, USA, 195.

Parmar, P. and Sindhu, S. S. (2013), "Potassium solubilization by rhizosphere bacteria: influence of nutritional and environmental conditions", Journal Microbiol Research, Vol. 3 No. 1, pp. 25-31.

Prajapati, K., Sharma, M. C. and Modi, H. A. (2013), "Growth promoting effect of potassium solubilizing microorganisms on okra (Abelmoscus esculantus)", International Journal Agricultural Sciences, Vol. 3 No. 1, 
pp. $181-188$.

Sharma, R. C and Sud, K. C. (2001), "Potassium management for yield and quality of potato", Proceedings of an International Symposium on the role of potassium in nutrient management for sustainable crop production in India, pp. 363-381.

Shehata, S. A., El-Helaly, M. A. and ElSaid, M. A. (2014), "Using natural alternative fertilizers for potato production under sandy soil conditions in Egypt", Journal of Plant Production, Vol. 5 No. 10, pp. 1745-1757.

Singh, M., Biswas, S. K., Nagar, D., Lal, K. and Singh, J. (2017), "Impact of bio-fertilizer on growth parameters and yield of potato", International Journal of Current Microbiology and Applied Sciences, Vol. 6 No. 5, pp. 1717-1724.

Xiao, Y., Wang, X., Chen, W. and Huang, Q. (2017), "Isolation and identification of three potassiumsolubilizing bacteria from rape rhizospheric soil and their effects on ryegrass", Geomicrobiology

Journal, Vol. 34 No. 10, pp. 873880.
Youssef, G. H., Seddik, W. M. and Osman, M. A. (2010), "Efficiency of natural minerals in presence of different nitrogen forms and potassium dissolving bacteria on peanut and sesame yields", Journal American Sciences, Vol. 6 No. 11, pp. 647-660.

Zaki, M. F., Tantawy, A. S., Saleh, S. A. and Helmy, Y. I. (2012), "Effect of bio-fertilization and different levels of nitrogen sources on growth, yield components and head quality of two broccoli cultivars", Journal of Applied Sciences Research, Vol. No. 8, pp. 3943-3960.

Zhang, A. M., Zhao, G. Y., Gao, T. G., Wang, W., Li, J., Zhang, S. F. and Zhu, B. C. (2013), "Solubilization of insoluble potassium and phosphate by Paenibacillus kribensis CX-7: a soil microorganism with biological control potential", African Journal of Microbiology Research, Vol. 7 No. 1, pp. 41-47. 